\title{
Leadership Talk by the Bishop of the Protestant Church of Austria (2008-2019)
}

Antisemitism is not in accordance with the Christian faith or the values of the Protestant Church. Today, we see this as a generally accepted fact. However, a couple of decades ago, this sentiment would have not been so certain. The Protestant Church of Austria was inflicted by German nationalism and Antisemitism during the first half of the twentieth century. Anti-Jewish pamphlets by Martin Luther and other reformers had a particularly adverse impact, too.

The Protestant Church only began reconsidering the issue after the war in 1945. While the Roman Catholic Church as a whole committed to a strong opposition against antisemitism in their Conciliar Declaration Nostra Aetate in 1965, within the Protestant Church, each regional church had to go its own way. ${ }^{1}$ Some regional churches progressed faster than others. The Evangelical Church in the Rhineland, for example, issued the important Synod decision "On the Renewal of the Relationship between Christians and Jews" in 1980. ${ }^{2}$ Other regional churches followed, some with considerable delay. With their declaration "A Time for Change," the Protestant Church of Austria accepted its joint guilt and responsibility only in 1998 and made way for a new relationship with Judaism. ${ }^{3}$

All Protestant declarations clearly and roundly condemn and oppose antisemitism. What was new about the declarations from the 1980's and 1990's was the Church's understanding of the consequences these declarations should and must have both for the Church and within the Church. These consequences first and foremost concern the joint guilt and responsibility of the Churches concerning antisemitism, a phenomenon also stemming from a Christian Jew-hatred that is hundreds of years old. Second came the need to examine our own doctrines and practices to rid them of antisemitic elements. These ele-

The English Translation of the original contribution in German was done by Kerstin Mayerhofer.

1 His Holiness, Pope Paul VI, Nostra Aetate: Declaration On The Relation Of The Church To NonChristian Religions, issued October 28, 1965, accessed July 17, 2018, http://www.vatican.va/ar chive/hist_councils/ii_vatican_council/documents/vat-ii_decl_19651028_nostra-aetate_en.html. 2 “Zur Erneuerung des Verhältnisses von Christen und Juden,” Landessynode 1980, accessed July 19, 2018, https://www.ekir.de/www/service/2509.php.

3 "Zeit zur Umkehr: Die Evangelischen Kirchen in Österreich und die Juden,” Erklärung der Generalsynode, issued November 1998, accessed July 19, 2018, https://evang.at/wp-content/up loads/2015/07/umkehr_011.pdf.

Ә OpenAccess. () 2019 Michael Bünker, published by De Gruyter. (cc) BY-NC-ND This work is licensed under the Creative Commons Attribution-NonCommercial-NoDerivatives 4.0 License. 
ments can be found in misinterpretations of biblical traditions as well as in a distorted view of Judaism and the meaning of Jesus's significance for both the Christian and Jewish faiths. A third focus was put on the relationship between Protestant Christians and Jews as well as with the Jewish communities as a whole. Fighting antisemitism always encompasses solidarity with our Jewish brothers and sisters in the here and now. In Austria, this sadly is a recurrent situation with a governing right-wing party and members of student fraternities singing antisemitic texts from their songbooks. As a fourth part, the Protestant Church has changed and strengthened its position regarding the State of Israel. This too is a logical consequence coming together with the fight against antisemitism. According to the "Working Definition of Antisemitism" by the International Holocaust Remembrance Alliance (IHRA), which Austria has recently adopted,

Manifestations (of antisemitism) might include the targeting of the state of Israel, conceived as a Jewish collectivity. However, criticism of Israel similar to that leveled against any other country cannot be regarded antisemitic. ${ }^{4}$

Already ten years prior, the Protestant Church of Austria stated the following:

60 years ago, on May $14^{\text {th }}$, 1948, the State of Israel was founded. The Protestant Churches of Austria congratulate all Israeli citizens on the jubilee of their state. After centuries of homelessness, discrimination, expulsion, and persecution that culminated into the Shoah, Jews have now found refuge in a newly founded state. Due to the centuries-long Jew-hatred that continues until modern times, the Protestant Church too is guilty of the untold misery of the Jewish people. We most support our Christian brothers and sisters in Israel and Palestine in their continuous fight for peace and justice in which together with Jewish peace groups they see themselves as bridge builders between peoples and religions. We hope and pray that the state of Israel will find its peace alongside their neighbors, especially with the Palestine people, on the basis of mutual respect for the right of residence so that one day, Israelis and Palestinians, Jews, Christians, and Muslims will be living together in what will be a fruitful community and future in the same land. ${ }^{5}$

4 "Working Definition of Antisemitism," International Holocaust Remembrance Alliance (IHRA), issued May 26, 2016, accessed July 19, 2018, https://www.holocaustremembrance.com/ sites/default/files/press_release_document_antisemitism.pdf.

5 ““60 Jahre Staat Israel’: Erklärung des Evangelischen Oberkirchenrates A.u.H.B,” Evangelischer Oberkirchenrat A.u.H.B, issued May 6, 2008, accessed July 19, 2018, https://evang.at/wpcontent/uploads/2015/07/080506_OKR_60JahreIsrael.pdf. Original text: "Vor 60 Jahren, am 14. Mai 1948, wurde der Staat Israel gegründet. Die evangelischen Kirchen in Österreich gratulieren seinen Bürgerinnen und Bürgern zu diesem Jubiläum. Nach jahrhundertelanger Heimatlosigkeit, Diskriminierung, Vertreibung und Verfolgung, die schließlich in der Shoah gipfelte, fanden Jüdinnen und Juden eine Zufluchtsstätte in dem neu errichteten Staat. Aufgrund der bis in die jüngste Geschichte andauernden Judenfeindschaft haben auch die evangelischen Kirchen in 
In 2011, the first statement concerning Judaism encompassing all Protestant Churches was issued. It was compiled by the "Community of Protestant Churches in Europe" (CPCE) and recommended to roughly one hundred member churches and communities. In this statement, the commitment against antisemitism is combined with basic theological understandings of the relationship between Judaism and Christianity from an Protestant point of view. The renewal of the relationship hereby is based on the following insights:

[...] recognition of the abiding election of the Jewish people the recognition of the Jewish roots of the Christian faith the recognition of the indissoluble bond between the Church and Israel renunciation of mission to the Jews recognition of the central role of the state of Israel for Judaism, along with efforts at the same time for a just and peaceful resolution of the Middle East conflict admission of Christian co-responsibility and guilt for the Shoah the irreconcilability of Christian faith with anti-Semitism and all forms of hatred for Jews. ${ }^{6}$

However, some critical questions remain open. It is not clear if declarations issued by church leaderships and expert commissions always reach all parishes and communal working areas, such as religious education. Also, do they reach church members who are not participating in an active church life and communication?

The report by the "Unabhängiger Expertenkreis Antisemitismus" ["Independent Body of Experts on Antisemitism"] for the German Bundestag from April 2017 has reported, based on an empirical survey, that church membership does not have clear effects on whether or not a person is free from antisemitic prejudices. $^{7}$ This sobering report makes clear that for our Church there is still a lot of work to do.

Österreich Mitschuld am unermesslichen Leid des jüdischen Volkes. Als evangelische Kirchen unterstützen wir besonders unsere christlichen Geschwister in Israel und in Palästina, die sich seit Jahren als Vorkämpfer für einen gerechten Frieden einsetzen und sich gemeinsam mit jüdischen Friedensgruppen als Brückenbauer zwischen den Völkern und Religionen betätigen. Wir hoffen und beten, dass der Staat Israel mit seinen Nachbarn, insbesondere mit dem palästinensischen Volk, in gegenseitiger Achtung des Heimatrechtes einen sicheren und gerechten Frieden findet, sodass Israelis und Palästinenser, Juden, Christen und Muslime in fruchtbringender Gemeinschaft im Land miteinander in Zukunft leben können.”

6 "Closing Communiqué of the Consultation 'Church and Israel'-A Reappraisal," Community of Protestant Churches in Europe (CPCE), issued June 19, 2011, accessed July 19, 2018, http:// www.leuenberg.eu/press-release/international-conference-state-relations-between-christiansand-jews.

7 "Antisemitismusbericht 18/11970: Bericht des Unabhängiger Expertenkreises Antisemitismus," issued April 7, 2017, accessed July 19, 2018, http://dip21.bundestag.de/dip21/btd/18/119/ 1811970.pdf, 198-201. 
Michael Bünker was served as Bishop of the Lutheran Church in Austria (Evangelische Kirche A.B. in Österreich) from 2008 until summer 2019. From 2006 to 2018 he also was the General Secretary of the "Community of Protestant Churches in Europe (CPCE)". The Lutheran and the Reformed Church in Austria are committed in good dialogue and trustful relations with the Jewish Community in Austria ("Zeit zur Umkehr" 1998).

\section{Bibliography}

Community of Protestant Churches in Europe (CPCE). "Closing Communique of the Consultation 'Church and Israel'-A Reappraisal.” Issued June 19, 2011. Accessed July 19, 2018. http://www.leuenberg.eu/press-release/international-conference-state-relations-be tween -christians-and-jews.

Evangelischer Oberkirchenrat A.u.H.B. “"60 Jahre Staat Israel’: Erklärung des Evangelischen Oberkirchenrates A.u.H.B.” Issued May 6, 2008. Accessed July 19, 2018. https://evang. at/wp-content/uploads/2015/07/080506_OKR_60Jahrelsrael.pdf.

Evangelischer Oberkirchenrat A.u.H.B; Landessynode 1980. "Zur Erneuerung des Verhältnisses von Christen und Juden.” Accessed July 19, 2018. https://www.ekir.de/ www/service/2509.php.

Evangelischer Oberkirchenrat A.u.H.B; Generalysonode 1998. "Zeit zur Umkehr: Die Evangelischen Kirchen in Österreich und die Juden.” Issued November 1998. Accessed July 19, 2018. https://evang.at/wp-content/uploads/2015/07/umkehr_011.pdf.

Pope Paul VI, Nostra Aetate: Declaration On The Relation Of The Church To Non-Christian Religions. Issued October 28, 1965. Accessed July 17, 2018. http://www.vatican.va/ar chive/hist_councils/ii_vatican_council/documents/vat-ii_decl_19651028_nostra-aetate_ en.html.

International Holocaust Remembrance Alliance (IHRA). "Working Definition of Antisemitism." Issued May 26, 2016. Accessed July 19, 2018. https://www.holocaustremembrance.com/ sites/default/files/press_release_document_antisemitism.pdf.

Schwier, Helmut, ed. Kirche und Israel. Ein Beitrag der reformatorischen Kirchen Europas zum Verhältnis von Christen und Juden. Frankfurt: Otto Lembeck, 2004.

Unabhängiger Expertenkreis Antisemitismus. "Antisemitismusbericht 18/11970: Bericht des Unabhängigen Expertenkreises Antisemitismus.” Issued April 7, 2017. Accessed July 19, 2018. http://dip21.bundestag.de/dip21/btd/18/119/1811970.pdf. 